\title{
Isotherm Study in Arsenic Tolerant Bacteria Isolated from Arsenic Affected Area in West-Bengal, India
}

\author{
Debanjana Sengupta ${ }^{1}$,Arup Kumar Mitra ${ }^{*}$, Sudeshna Shyam Choudhury ${ }^{1}$, \\ Ayan Chandra ${ }^{2}$ \\ 1. P.G. Department of Microbiology, St. Xavier's College,Kolkata,West-Bengal,India. \\ 2. Department of Statistics, St. Xavier's College,Kolkata,West-Bengal,India.
}

\begin{abstract}
Biosorption of arsenic and iron using arsenic tolerent bacteria i.e Bacillus sp. strain CCBAU 51490 (C-7) and Bacillus subtilis subsp. subtilis strain DSM $10(A-2)$ isolated from halophilic arsenic contaminated soil of Baduria [Arsenic (As) concentration of the soil is 2.18 ppm.] after exposing them to $50 \mathrm{mg} / \mathrm{l}$. and $30 \mathrm{mg} / \mathrm{l}$ of arsenic respectively and $42 \mathrm{mg} / \mathrm{l}$. of iron $(\mathrm{Fe})$ in primary and ternary solutions. The Langmuir and Freundlich adsorption isotherm models were used in the equilibrium modeling for determining the ideal condition for arsenic removal from contaminated sludge with this resistant bacterial consortium. Both the adsorption isotherm models were found to fit accurately with the experimental data. The best condition of the biosorption of arsenic by $C-7$ and A-2 bacteria are $700 \mu l$ of the bacterial culture aliquot (3.612 $\times 10^{8}$ no. of cells of $0.0607 \mathrm{~g}$. dry wt.) at pH 7 in $50 \mathrm{mg} . / \mathrm{l}$ arsenic supplemented $30 \mathrm{ml}$. media at $37^{\circ} \mathrm{C}$ temperature and $300 \mu \mathrm{l}$ of the bacterial culture aliquot $\left(1.29 \times 10^{7}\right.$ no. of cells of $0.019 \mathrm{~g}$. dry wt. respectively) at $\mathrm{pH} 7$ in $30 \mathrm{mg} . / \mathrm{l}$ of arsenic concentration containing $30 \mathrm{ml}$. media at $37^{\circ} \mathrm{C}$ temperature, where the bacteria can take up $62.34 \%$ and $22.17 \%$ of As respectively. This condition satisfies both pseudo-first order and pseudo-second order rate kinetics graphs.The bacterial arsenic biosorption shows the different pattern in presence of iron i.e C-7 bacteria can uptake $47.08 \%$ of As from the ternary solution instead of $62.34 \%$ of As from the primary solution and A-2 can uptake $33.7 \%$ of As from the ternary solution instead of $22.17 \%$ of As from the primary solution after 24 hours.
\end{abstract}

Keywords: Arsenic and iron biosorption, Bacillus sp. strain CCBAU 51490,Bacillus subtilis subsp. subtilis strain DSM 10, Differential rate kinetics equation, Langmuir and Freundlich adsorption isotherm model,

\section{Introduction}

Water is the most valuable natural resource in our planet because earth's surface comprises $70 \%$ of water and the life on the earth would not exist without it. Although this fact is widely recognized, pollution of water resources is a common problem being faced today (Tarangini, 2009). Heavy metal pollution causes directly by the effluents of industries, refineries and waste treatment plants as well as natural disaster like volcanic eruption followed by low-temperature volatization.The pollutants enter the water supply from soils/ground water systems, natural water bodies like lakes,rivers and ocean etc and from the atmosphere via rain water (Vijayaraghavan and Yun, 2008). These pollutants are mainly the toxic and hazardous heavy metals (Vieira and Volesky, 2000), which may accumulate in the organisms under certain environmental condition and cause ecological damage (Jefferies and Firestone, 1984). In case of arsenic EPA (Environmental Protection Agency) has set the arsenic standard for drinking water at $0.010 \mathrm{mg} / \mathrm{l}$ (http://water.epa.gov/drink/contaminants). Among the different biological methods (for eg. precipitation, adsorption, ion exchange, membrane and electrochemical technologies) bioaccumulation and biosorption have been demonstrated to possess good potential to replace conventional methods for the removal of metals (Volesky and Holan, 1995; Malik, 2004) because it is eco-friendly and cost effective. Both Gram + ve and Gram -ve bacteria can absorb the heavy metals easily due to the metabolically binding of ions onto the cell surface (Binkley \& Simpson 2003) and metabolic production of binding protein (Samuelson et al. 2000).

The present investigation was undertaken to find the most effective condition of arsenic tolerance of Bacillus sp. strain CCBAU 51490 and Bacillus subtilis subsp. subtilis strain DSM 10 by isotherm modeling to calculate the rate kinetics equation for the biosorption in presence of arsenic and the amount of arsenic uptake was also determined in the same way in the presence of iron.

\section{Materials And Methods}

\subsection{INOCULATION AND BIOSORPTION OF THE BACTERIAL CULTURE}

The inoculation and biosorption of the bacterial culture was done according to Pathak and Dikshit, 2011.The bacteria [C-7 and A-2 bacteria Fig. 1(A) and 1(B)] were grown in the nutrient agar medium containing $0.3 \mathrm{gm}$. of beef extract,0.5 gm. of peptone, $0.5 \mathrm{gm}$. of $\mathrm{NaCl}$ and $2 \mathrm{gm}$. of Agar in the $100 \mathrm{ml}$. of water. Pure 
culture were obtained by subculture and pure culturing technique from the isolated colonies. Then they were transferred to the nutrient broth and allowed to grow overnight at $37^{\circ} \mathrm{C}$ in B.O.D. incubator shaker.

Biosorption studies were done using biomass as a function of various parameters such as

a) $\mathrm{pH}$

b) Biomass concentration

c) Temperature

\subsubsection{GROWTH OF THE BACTERIA IN THE PRIMARY SOLUTION (a) EFFECT OF pH OF THE MEDIA}

The bacterial metal sorption was monitored for $\mathrm{pH}$ range 5, 7 and 10 (Ferreira and Lund, 1987, Tarangini, 2009). Citrate and bicarbonate-carbonate buffer $\mathrm{pH} 5$ and $\mathrm{pH} 10$ respectively were used for maintaining the proper $\mathrm{pH}$ i.e. $\mathrm{pH} 5$ and $\mathrm{pH} 10$ respectively in the media and $\mathrm{NaOH}$ and $\mathrm{HCl}$ were used as $\mathrm{pH}$ regulators. $1 / 100^{\text {th }}$ part of biomass $(\mathrm{v} / \mathrm{v})$ was dispersed in $30 \mathrm{ml}$ of the media containing $50 \mathrm{mg} / \mathrm{l} \mathrm{and} 30 \mathrm{mg} / \mathrm{l} \mathrm{of}$ arsenic (As) concentration for the two bacterial strains respectively. All flasks were maintained at different $\mathrm{pH}$ values i.e 5,7 and 10 for about 24 hours. Solutions were centrifuged (Remi C-24) at 9,000 r.p.m. for 10 minutes and the supernatant was analyzed for the residual concentrations of the metal ions.

\section{(b) EFFECT OF THE BACTERIAL BIOMASS CONCENTRATION}

According to Tarangini, 2009, Zhu, 2010 and Babak et al, 2012, the effect of the bacterial biomass concentration on the biosorption study was done. Biomass was centrifuged at 9,000 rpm for 10 minutes and different weights of the biomass ranging from $300 \mu$ l.to $900 \mu \mathrm{l}$. (from $1.548 \times 10^{8}$ to $4.64 \times 10^{8}$ no. of cells in case of C-7 bacteria and $1.29 \times 10^{7}$ to $3.87 \times 10^{7}$ no. of cells in case of A-2 bacteria) aliquots were dispersed in $30 \mathrm{ml}$. media containing the $50 \mathrm{mg} / \mathrm{l}$ and $30 \mathrm{mg} / \mathrm{l}$ of arsenic (As) concentration at the optimum $\mathrm{pH}$ i.e $\mathrm{pH} 7 \mathrm{for}$ the two bacterial strains respectively. The solutions were adjusted to the optimum $\mathrm{pH}$ in which maximum biosorption of the metal ion occurred by the two bacteria. Flasks were left on the shaker of B.O.D. incubator shaker at $37^{\circ} \mathrm{C}$ for equilibration. The solutions were later centrifuged at 9,000 r.p.m for 10 minutes (Remi C-24) and the metal ion concentrations were determined from the supernatents using the procedures described later.

\section{(c) EFFECT OF TEMPERATURE OF THE BACTERIAL INCUBATION}

According to Tarangini, 2009, Pathak and Dikshit, 2011, Babak et al, 2012, the effect of various temperature on the bacterial heavy metal adsorption study was shown. The optimum biomass concentration i.e $700 \mu \mathrm{l}$. culture aliquot containing $3.612 \times 10^{8}$ no. of cells of $0.0607 \mathrm{~g}$. dry weight in case of C-7 bacteria and 300 $\mu$ l. culture aliquot containing $1.29 \times 10^{7}$ no. of cells of $0.019 \mathrm{~g}$. dry weight in case of A-2 bacteria with optimum $\mathrm{pH}$ i.e $\mathrm{pH} 7$ was used to monitor the temperature effect on biosorption of arsenic (As) from the arsenic supplemented media (which was described earlier) by the two bacterial strains. The experiments were carried out at the different temperatures i.e $21^{\circ} \mathrm{C}, 30^{\circ} \mathrm{C}$ and $37^{\circ} \mathrm{C}$ for $\mathrm{C}-7$ bacteria and $37^{\circ} \mathrm{C}, 30^{\circ} \mathrm{C}$ for $\mathrm{A}-2$ bacteria and kept the culture flasks the shaker of the B.O.D. incubator shaker, which were set at the different temperatures. The samples were allowed to attain equilibrium. The samples were collected at their stationary growth phase.Then they were centrifuged (Remi C-24) at 9,000 r.p.m. for 10 minutes and the supernatents were analyzed for metal concentration.

\section{(d) ANALYTICAL ESTIMATION OF ARSENIC}

The concentrations of Arsenic in the samples were measured by ICP-OES (Thermo Scientific, Model No. ICAP 6000 Duo).The most sensitive lines for arsenic (Sengupta et al, 2013) lie in the UV region (193.759 $\mathrm{nm}$.) and an appropriate spectrophotometer would be used.

\subsection{ADSORPTION ISOTHERMS}

According to Tarangini, 2009 and Zhu, 2010 the optimum biomass of each culture was dispersed in a desired concentration i.e 50mg/l and $30 \mathrm{mg} / \mathrm{l}$ of arsenic for C-7 and A-2 bacteria respectively in their optimum medium $\mathrm{pH}$ and temperature. The culture flasks were incubated for their respective period of time at the end of which the residual concentrations were determined.

\section{FORMULA AND EQUATIONS USED}

The amount of metal bound by the biosorbents i.e the biomass of the bacterial cells was calculated as follows

$\mathrm{Q}=\mathrm{v}(\mathrm{Ci}-\mathrm{Cf}) / \mathrm{m}$

Where $\mathrm{Q}$ is the metal uptake (mg metal per $\mathrm{g}$ biosorbent), $\mathrm{v}$ is the liquid sample

volume $(\mathrm{ml}), \mathrm{Ci}$ is the initial concentration of the metal in the solution $(\mathrm{mg} / \mathrm{l}), \mathrm{Cf}$ is the final (equilibrium) concentration of the metal in the supernatant $(\mathrm{mg} / \mathrm{l})$ and $\mathrm{m}$ is the amount of the added biosorbent i.e. the dry weight of the bacterial biomass ( $\mathrm{mg})$. 
The Langmuir model, $\mathrm{Q}=\mathrm{Qmax}$ bCf/ 1+bCf.

Where Qmax is the maximum metal uptake under the given conditions, $\mathrm{b}$ a constant related to the affinity between the biosorbent and sorbate.

Linearized Langmuir model

$1 / \mathrm{Q}=1 / \mathrm{Qmax}(1 / \mathrm{b} \mathrm{Cf}+1)$.

The Freundlich Model,

$\mathrm{Q}=\mathrm{k} \mathrm{Cf}(1 / \mathrm{n})$

Where $\mathrm{k}$ and $\mathrm{n}$ are Freundlich constant, which correlated to the maximum adsorption capacity and adsorption intensity, respectively.

Linearized Freundlich equation

$\log \mathrm{Q}=\log \mathrm{k}+1 / \mathrm{n} \log \mathrm{Cf}$.

Equation (1) and (2) can be solved using least square technique, equation (3) using quantile regression, equation (4) using modified least square and equation (5) using computerized method.

\subsection{2.(a) GROWTH OF THE BACTERIA IN THE TERNARY SOLUTION}

The method was done according to Borrok et al., 2006 ,Parungao et al, 2007, Tarangini, 2009 and Zhu, 2010.The bacterial seed cultures were inoculated in $30 \mathrm{ml}$. media supplemented with $50 \mathrm{mg} / \mathrm{l}$ and $30 \mathrm{mg} / \mathrm{l} \mathrm{of}$ arsenic (As) ( for C-7 and A-2 respectively) and $42 \mathrm{mg} . / \mathrm{l}$ of iron (Fe) (the ternary solution) with maintaining the optimum growth condition for the heavy metal uptake.The growth of the bacteria was measured by Colorimetric assay at $580 \mathrm{~nm}$. filter. Then the samples were collected at their stationary growth phase and they were centrifuged (Remi-C24) at 9,000 r.p.m. for 10 minutes. After centrifugation the supernatents were analyzed for the residual As and Fe concentration.

\section{(b) ANALYTICAL ESTIMATION OF ARSENIC AND IRON}

The residual concentration of As (as mentioned earlier according to Sengupta et al., 2013) and Fe were measured by ICP-OES (Thermo Scientific, Model No. ICAP 6000 Duo). In ICP-OES, the concentration of iron in the solutions were measured at $259.940 \mathrm{~nm}$. of UV range of the spectrophotometer.

\section{1(a). EFFECT OF pH OF THE MEDIA}

\section{Results}

In this study it is observed that the growth of C-7 and A-2 bacteria i.e Bacillus sp. strain CCBAU 51490, Bacillus subtilis sub sp. subtilis strain DSM 10 is much better in pH 7 [Fig. 2(B), 2(F)] medium than pH 5 [Fig. 2(A), 2(E) and pH 10 (Fig. 2(C), 2(G)]. In pH 5 medium because the static phase of the bacteria arrived in just 4 hours and the growth of the bacteria was very low which was measured by the O.D. value in $580 \mathrm{~nm}$. filter.The percentage uptake of As $(43.2 \%, 22.17 \%)$ was also higher in $\mathrm{pH} 7$ medium than in $\mathrm{pH} 10(35.8 \%$, $8.53 \%$ ) medium by the such bacteria i.e C-7 and A-2 respectively [Fig. 2(D), 2(H)].So, pH 7 is the optimum pH for growth and percentage uptake of the metal by the bacteria and it was constant in next experimental parameter i.e biomass of the bacteria.

\section{(b) EFFECT OF THE BACTERIAL CONCENTRATION}

The growth of C-7 and A-2 bacteria was higher in in case of dry weight $\left(0.0607 \mathrm{~g}\right.$., $3.612 \times 10^{8}$ no. of cells and 0.019 g., $1.29 \times 10^{7}$ no. of cells) of $700 \mu l$. and $300 \mu 1$ aliquot [Fig. 3(C) and 3(F)] than the dry weights of the different aliquots of the both bacteria respectively [Fig. 3(A),3(B),3(D) and 3(G), 3(H),3(I) respectively]. C-7 and A-2 bacteria can uptake $62.34 \%$ and $22.17 \%$ of As by its $0.0607 \mathrm{~g}$. and $0.019 \mathrm{~g}$. of dry weight of $700 \mu \mathrm{l}$. and $300 \mu \mathrm{l}$. aliquot respectively [Fig. 3(E) and $3(\mathrm{~J})]$, which are the highest percentage uptake of As value than the other different biomass of the both bacterial inoculums. So, the optimum condition for the growth and as well as the percentage uptake of arsenic by the both bacteria was found and it remains constant in the next experimental parameter i.e temperature.

\section{(c) EFFECT OF TEMPERATURE OF THE BACTERIAL INCUBATION}

The growth and percentage uptake of As by $0.0607 \mathrm{~g}$. dry weight of $3.612 \times 10^{8}$ no. of cells of $700 \mu$ l. aliquot of C-7 bacteria and $0.019 \mathrm{~g}$. dry weight of $1.29 \times 10^{7}$ no. of cells $300 \mu$ l. aliquot of of A-2 bacteria were the highest in $37^{\circ} \mathrm{C}(62.34 \%$ and $22.17 \%$ respectively) than in the other different temperatures [Fig. 4(A),4(B),4(C) and 4(D) and 4(E), 4(F), 4(G)]. 


\subsection{ADSORPTION ISOTHERM AND RATE KINETICS}

C-7 and A-2 bacteria i.e Bacillus sp. strain CCBAU 51490 and Bacillus subtilis subsp. subtilis strain DSM 10 can exhibit an uptake of $62.34 \%$ and $22.17 \%$ of As respectively.Fig. 6(A), 6(B) depict Freundlich isotherm model of Bacillus sp. strain CCBAU 51490 and Bacillus subtilis subsp. subtilis where the depression zone of the curve is indicated the highest uptake of As in the optimum growth condition of these two bacteria.This condition satisfies both pseudo-first order and pseudo-second order rate kinetics graphs, which are made on the basis of the pseudo-first order and pseudo-second order differential equation $d_{t} / d_{t}=k_{1}\left(q_{e}-q_{t}\right)$ and $\mathrm{dq}_{\mathrm{t}} / \mathrm{d}_{\mathrm{t}}=\mathrm{k}_{2}\left(\mathrm{q}_{\mathrm{e}}-\mathrm{q}_{\mathrm{t}}\right)^{2}$ of Yang and Duri, 2005, where $\mathrm{q}_{\mathrm{e}}(\mathrm{mg} \mathrm{g}-1)$ is the solid phase concentration at equilibrium, $\mathrm{q}_{\mathrm{t}}$ (mg g-1) is the average solid phase concentration at time $\mathrm{t}(\mathrm{min})$, and $\mathrm{k}_{1}(\mathrm{~min}-1)$ and $\mathrm{k}_{2}(\mathrm{~g} \mathrm{mg}-1 \mathrm{~min}-1)$ are the pseudo-first-order and pseudo-second order rate constants, respectively and from these equations, $\ln \left(\mathrm{q}_{\mathrm{e}^{-}}\right.$ $\left.\mathrm{q}_{\mathrm{t}}\right)=\ln \left(\mathrm{q}_{\mathrm{e}}\right)-\mathrm{k}_{1} \mathrm{t}$ and $\mathrm{t} / \mathrm{q}_{\mathrm{t}}=1 / \mathrm{k}_{2} \mathrm{q}_{\mathrm{e}}{ }^{2}+\mathrm{t} / \mathrm{q}_{\mathrm{e}}$ equations are derived, when $\mathrm{t}=0$ and $\mathrm{q}_{\mathrm{t}}=0$ in the initial condition.

Thus the absorption process of C-7 bacteria and A-2 i.e Bacillus sp. strain CCBAU 51490 and Bacillus subtilis subsp. subtilis strain DSM 10 in its optimum growth condition obeys pseudo-first order rate equation [Fig. 10(A), 8(C)] and as well as pseudo-second order rate equation [Fig. 10(B), 8(D)], while the other growth conditions of the same bacteria obey only pseudo-second order equation(Fig.7(A),7(B), 8(A), 8(B), 9(A),9(B),11(A),11(B),12(A),12(B),13(A),13(B)) because Fig. 10(A) and 8(C) depicts that the logarithm of the difference between uptake of As by C-7 and A-2 bacteria respectively in the equilibrium state $\left(\mathrm{q}_{\mathrm{e}}\right)$ and the uptake of As by the same bacteria $\left(\mathrm{q}_{\mathrm{t}}\right)$ at time ' $\mathrm{t}$ ' is inversely proportional to the time which means the difference between the uptake of As value by the bacteria is decreased with the time.From Fig.10(B) and 8(D) it is shown that the uptake of As by the same bacteria $\left(\mathrm{q}_{\mathrm{t}}\right)$ at time ' $\mathrm{t}$ ' is directly proportional to the time ' $\mathrm{t}$ ' because $\mathrm{q}_{\mathrm{t}}$ increases with increasing time.From the rate kinetics study, the present study indicated that under the optimum growth condition, arsenic adsorption of C-7 reached the equilibrium concentration in 24 hours [Fig. $10(\mathrm{~A})$ and $10(\mathrm{~B})]$ and in this condition arsenic accumulation rate, arsenic uptake and the growth rate of C-7 was highest than the other growth conditions.But in case of A-2, the equilibrium condition was reached in only 2 hours [Fig. 8(C) and 8(D)], at its optimum growth condition which was the most significant than the other conditions.

Fig. 5(A) and Fig. 5(C) depicts the growth of C-7and A-2 bacteria in presence of both arsenic and iron in its optimum growth condition respectively.From Fig. 5(B) and 5(D) it is suggested that the comparison between the percentage uptake of As and $\mathrm{Fe}$ in both primary metal (single metal) solution and ternary metal (mixed metal) solutions which are $62.34 \%$ and $22.17 \%$ of As and $81.40 \%$ and $95.50 \%$ of $\mathrm{Fe}$ in primary metal solution and $47.08 \%$ and $33.7 \%$ of As and $78.67 \%$ and $43.81 \%$ of Fe respectively in ternary metal solutions indicating the stronger competitive sorption of the metals by the bacteria.

\section{Discussion}

Adsorption process is usually described through isotherm models, that is, the amount of sorbed particles on the adsorbent materials as a functional effect of its pressure (if gas) or concentration (if liquid) at constant temperature and the quantity adsorbed substances are nearly always accumulated by the mass of the adsorbent to allow comparison of different materials (Foo and Hameed, 2010). According to Ying, C.P., 2007 Foo and Hameed, 2010 adsorption isotherm models are generally in three types;(i) Langmuir model, which suggests as a hypothesis, that is the uptake occurs on a homogeneous surface by monolayer sorption without interaction between sorbed molecules. Langmuir adsorption equation is applicable under the conditions of low pressure.(ii)The Freundlich model proposes a monolayer sorption with a heterogeneous energetic distribution of active sites and with interactions between sorbed molecules,(iii) Redlich and Peterson isotherms present a general isotherm equation in agreement with that of Langmuir and Freundlich isotherm models and (iv) BET Theory put forward by Brunauer, Emmett and Teller explained that multilayer formation is the true picture of physical Adsorption.

Pseudo first order second order kinetic models are the most popular model used to study the biosorption kinetics of heavy metals and to quantify the extent of uptake in biosorption kinetics. Both pseudo first and second order kinetics rate equation determines the decaying of the material at exponential rate.K.Tarangini,2009 carried the experiment of the biosorption of arsenic,chromium and mercury by the individual and mixed cultures of Bacillus subtilis and Pseudomonas aeruginosa where 32\%,30\% and 28\% arsenic, $81.3 \%, 60.5 \%$ and $77.6 \%$ chromium, $99.3 \%, 78.5 \%$ and $90.4 \%$ mercury were sorbed by the individual and mixed cultures of above mentioned two bacteria from the primary solution (single metal solution).In case of binary solution (two mixed metals solutions) the mixed cultures of two above mentioned bacteria sorbed 30\% chromium, $30 \%$ mercury and $20.9 \%$ arsenic and $70.7 \%$ mercury also indicating that the metals microbial interaction and the stronger competitive sorption of the metals by the bacteria. Pathak and Dikshit, 2011 showed the biosorption capabilities of the isolated four bacterial strains on the basis of their fast growth. John and Lara, 2011 showed the increased biosorption of $\mathrm{Cd}^{2+}$ from 2.48 to $9.81 \mathrm{mg} / \mathrm{g}$ and the maximum monolayer biosorption capacity of Cassia siamea was $37.7 \mathrm{mg}$./g. and they showed the rate kinetics of the $\mathrm{Cd}^{2+}$ uptake by the Pseudo- 
first order,psudo-second order and intra paricle diffusion model. Parungao et al.,2007 showed the removal of $22 \% \mathrm{Cu}, 24 \% \mathrm{Cd}$ and $42.75 \% \mathrm{~Pb}$ from the primary solutions (single metal solution) and removal of $16 \% \mathrm{Cu}, 8 \% \mathrm{Cd}$ and $35 \% \mathrm{~Pb}$ by Stenotrophomonas maltophilia (isolated from Mogpog river,Marinduque) from the ternary solutions (mixed metals solution). Borrok et al., 2007 reported that the ternary complexes had the effect of the mobility of aqueous metal cations in natural systems by changing dissolved NOM-metal complexes to colloidal bacteria-metal-NOM complexes. Zhu, 2010 reported that the competitive sorption of $\mathrm{Cr}$ and $\mathrm{Cu}$ by goethite-Bacillus thuringiensis, where $\mathrm{Cr}$ had the stronger affinity on the sorbents (Goethite-Bacillus thuringiensis than $\mathrm{Cu}$ ). Babak et al., 2012 showed the affinity order of the metals to the bacteria and they also reported that Geobacillus thermocatenulatus had the highest metal sorption capacities than Geobacillus thermodenitrificans.

The best effective condition of the biosorption of arsenic by Bacillus sp. strain CCBAU 51490 and Bacillus subtilis subsp. subtils strain DSM 10 (isolated from arsenic contaminated soil of Baduria,24 Parganas (North),West-Bengal,India are $0.0607 \mathrm{~g}$., $0.019 \mathrm{~g}$. dry weight of $700 \mu 1,300 \mu \mathrm{l}$. of the bacterial culture aliquot at $\mathrm{pH} 7,50 \mathrm{mg} / 1,30 \mathrm{mg} / 1$ of arsenic concentration and $37^{\circ} \mathrm{C}$ temperature, where the bacterial strain can uptake $62.34 \%$ and $22.17 \%$ of arsenic respectively (primary solution) which is the highest amount than the other growth conditions of the same bacteria [Fig.6(A),6(B) Freundlich Isotherm].So,this condition satisfies both pseudo-first order and pseudo-second order rate kinetics graphs and the absoption process obeys pseudo-first order rate equation and as well as pseudo-second order rate equation, while the other growth conditions of the same bacteria obey only pseudo-second order equation.From this present study it depicts the accumulation rate of As was high in A-2 than C-7 and As uptake capacity was significantly high in case of C-7 due to its cell density. But both bacteria reached their stationary growth phase within 24 hours of incubation.C-7 and A-2 bacteria can also uptake $81.40 \%, 95.50 \%$ of iron from the primary solution in its optimum growth condition and $47.08 \%, 33.7 \%$ of As and $78.67 \%, 43.81 \%$ of Fe respectively from ternary solutions, which indicates the competitive sorption of the two metal by the bacteria

\section{Conclusion}

The objective of the present study is to find the optimum growth condition, rate kinetics of the heavy metals uptake of the bacteria i.e, Bacillus sp. strain CCBAU 51490 and Bacillus subtilis subsp. subtilis strain DSM 10 These bacterial consortium will be used in the sludge treatment on the basis of their maximum percentage uptake of arsenic and iron from the primary and as well as ternary solution

\section{Acknowledgement}

We would like to thank Rev.Dr.John Felix Raj S.J.,Principal of St. Xavier's College,Kolkata for his continuous encouragement and support.

\section{FIGURES}

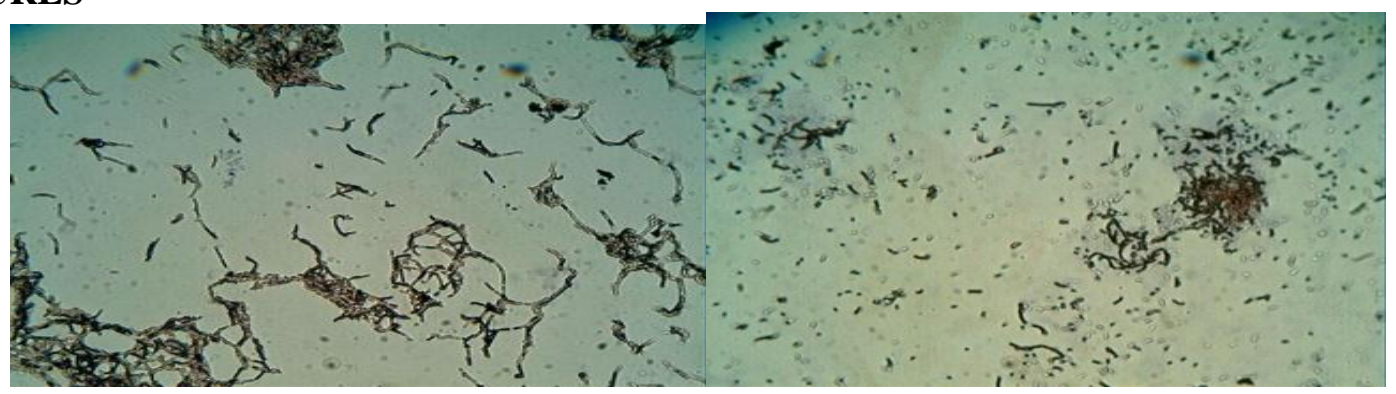

fig. 1(a)

fig. 1(b)

fig.1.(a) and (b). bacterial isolates (C-7) and (A-2) were grown on the nutrient agar media respectively.

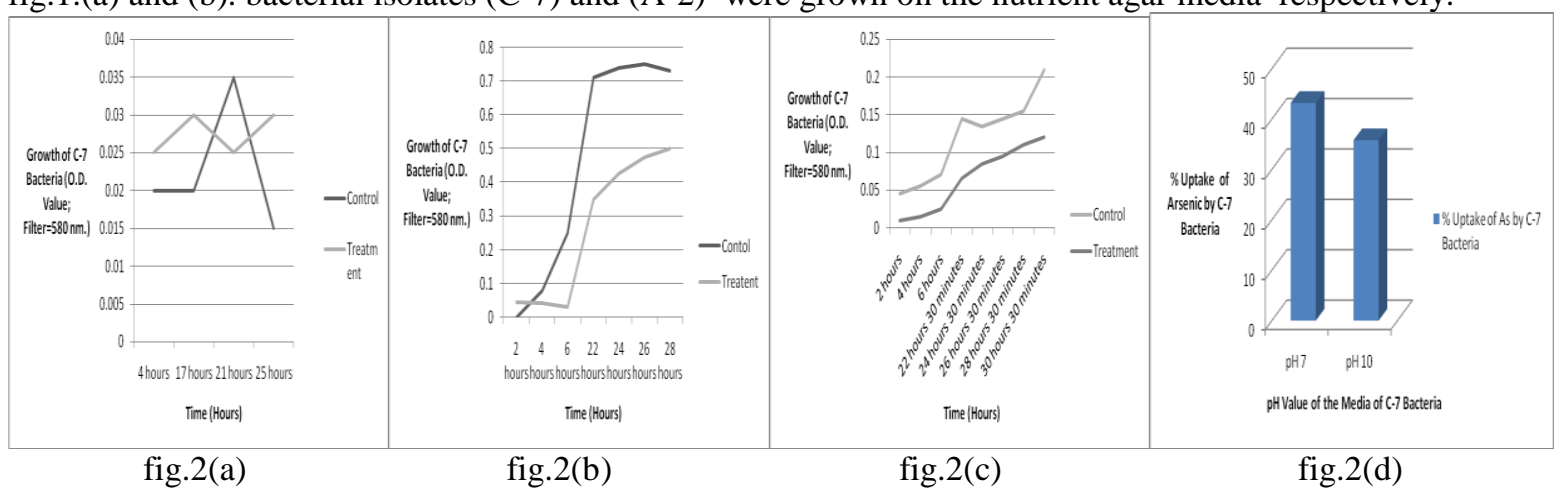


fig. 2.(a) growth curve of $\mathrm{C}-7$ bacteria at pH 5 medium in control and treatment condition, (b) growth curve of $\mathrm{C}-7$ bacteria at $\mathrm{pH} 7$ medium in control and treatment condition,(c) growth curve of $\mathrm{C}-7$ bacteria at $\mathrm{pH} 10$ medium in control and treatment condition and (d) \% uptake of arsenic by C-7 bacteria at various $\mathrm{pH}$

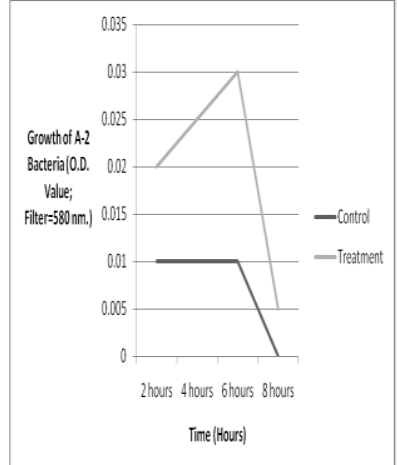

fig.2(e)

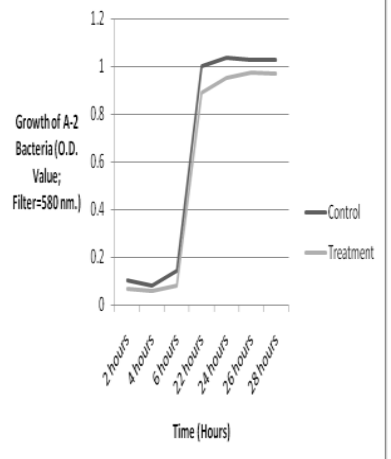

fig.2(f)

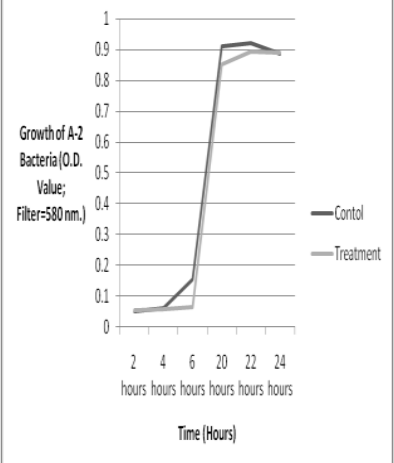

fig.2(g)

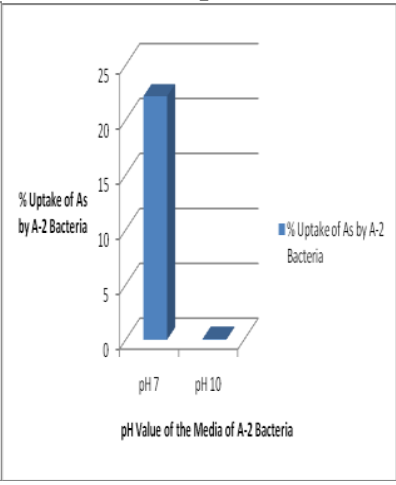

fig.2(h)

fig. 2.(e) growth curve of A-2 bacteria at pH 5 medium in control and treatment condition, (f) growth curve of A-2 bacteria at $\mathrm{pH} 7$ medium in control and treatment condition, (g) growth curve of A-2 bacteria at $\mathrm{pH} 10$ medium in control and treatment condition and (h) \% uptake of arsenic by A-2 bacteria at various $\mathrm{pH}$

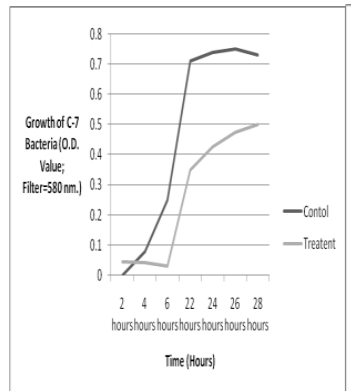

fig. 3(a)

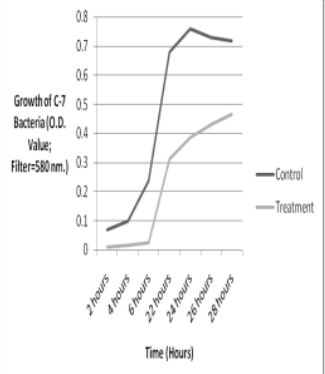

fig. 3(b)

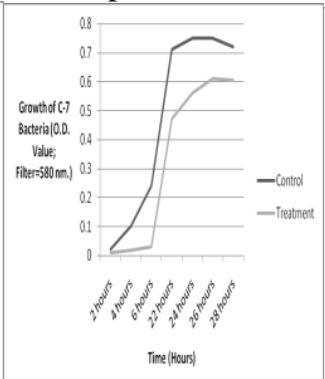

fig. 3(c)

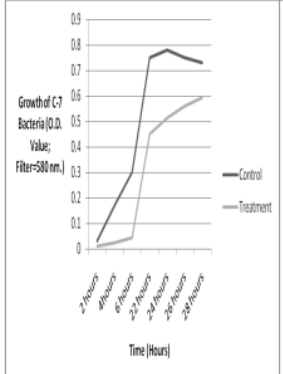

fig. 3(d)

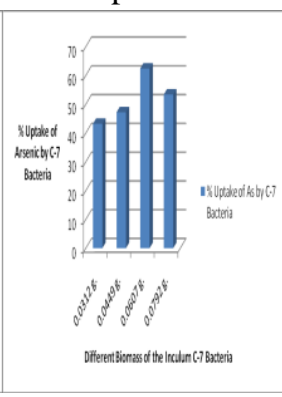

fig.3(e)

fig. 3(a) growth curve of $300 \mu \mathrm{l}$. aliquot i.e $0.0312 \mathrm{~g}$. of $\mathrm{C}-7$ bacteria at $\mathrm{pH} 7$ medium in control and treatment condition, (b) growth curve of $500 \mu$ l. aliquot i.e $0.0449 \mathrm{~g}$. of $\mathrm{C}-7$ bacteria at $\mathrm{pH} 7$ medium in control and treatment condition,(c) growth curve of $700 \mu \mathrm{l}$. aliquot i.e $0.0607 \mathrm{~g}$. of $\mathrm{C}-7$ bacteria at $\mathrm{pH} 7 \mathrm{medium}$ in control and treatment condition, (d) growth curve of $900 \mu \mathrm{l}$. aliquot i.e $0.0792 \mathrm{~g}$. of $\mathrm{C}-7$ bacteria at $\mathrm{pH} 7 \mathrm{medium}$ in control and treatment condition and (e) \%uptake of arsenic by c-7 bacteria in its different biomass at $\mathrm{pH} 7$ medium

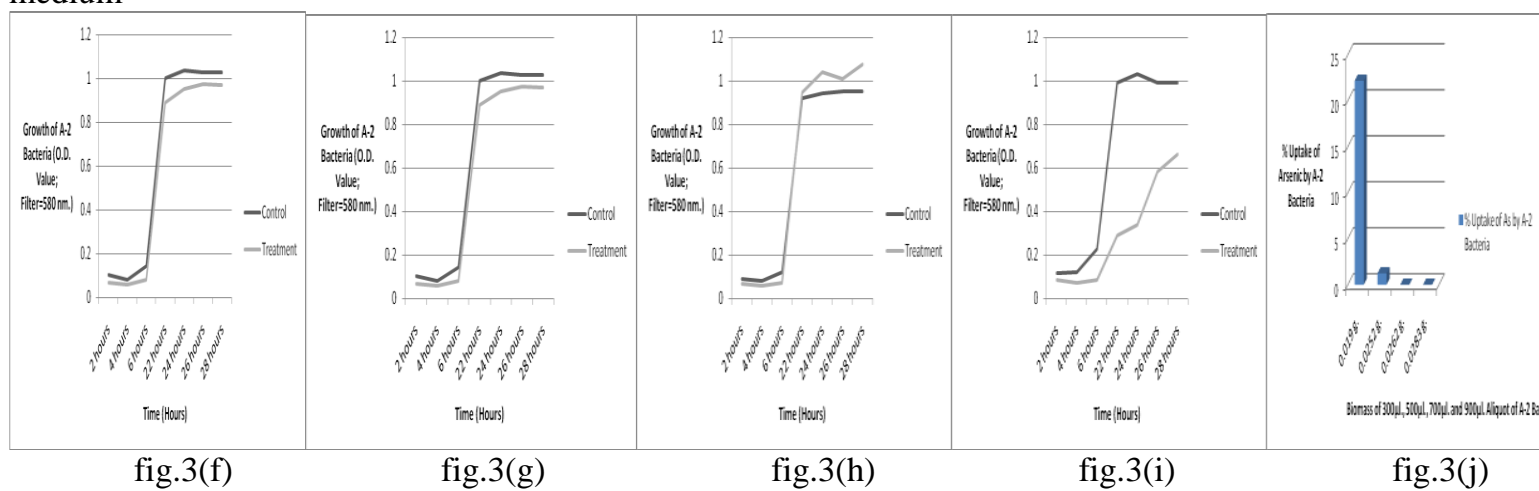

fig. 3(f) growth curve of $300 \mu \mathrm{l}$. aliquot i.e $0.0312 \mathrm{~g}$. of A-2 bacteria at $\mathrm{pH} 7$ medium in control and treatment condition, (g) growth curve of $500 \mu \mathrm{l}$. aliquot i.e $0.0449 \mathrm{~g}$. of A-2 bacteria at $\mathrm{pH} 7$ medium in control and treatment condition,(h) growth curve of $700 \mu 1$. aliquot i.e $0.0607 \mathrm{~g}$. of A-2 bacteria at $\mathrm{pH} 7 \mathrm{medium}$ in control and treatment condition,(i) growth curve of $900 \mu$ l. aliquot i.e $0.0792 \mathrm{~g}$. of A-2 bacteria at $\mathrm{pH} 7 \mathrm{medium}$ in control and treatment condition and (j) \%uptake of arsenic by A-2 bacteria in its different biomass at $\mathrm{pH} 7$ medium 


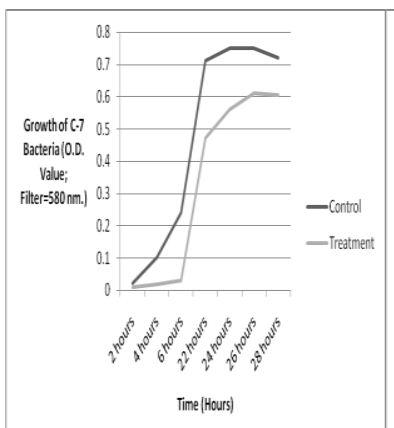

fig. 4(a)

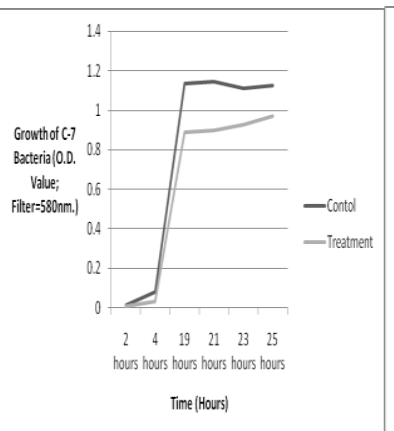

fig. 4(b)

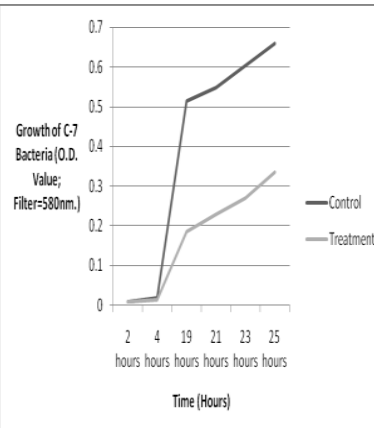

fig. 4(c)

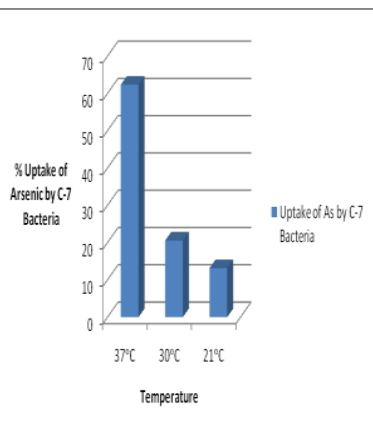

fig. $4(\mathrm{~d})$

fig. 4(a) growth curve of $700 \mu$ l. aliquot i.e $0.0607 \mathrm{~g}$. of $\mathrm{C}-7$ bacteria in $\mathrm{pH} 7$ medium at $37^{\circ} \mathrm{c}$ in control and treatment condition, (b) growth curve of $700 \mu$ l. aliquot i.e $0.0607 \mathrm{~g}$. of $\mathrm{C}-7$ bacteria in $\mathrm{pH} 7$ medium at $30^{\circ} \mathrm{c}$ in control and treatment condition, (c) growth curve of $700 \mu$ l. aliquot i.e $0.0607 \mathrm{~g}$. of C-7 bacteria in $\mathrm{pH} 7 \mathrm{medium}$ at $21^{\circ} \mathrm{c}$ in control and treatment condition and (d) \%uptake of arsenic by $700 \mu \mathrm{l}$. aliquot i.e $0.0607 \mathrm{~g}$. of C-7 bacteria in $\mathrm{pH} 7$ medium at $37^{\circ} \mathrm{c}, 30^{\circ} \mathrm{c}$ and $21^{\circ} \mathrm{c}$.

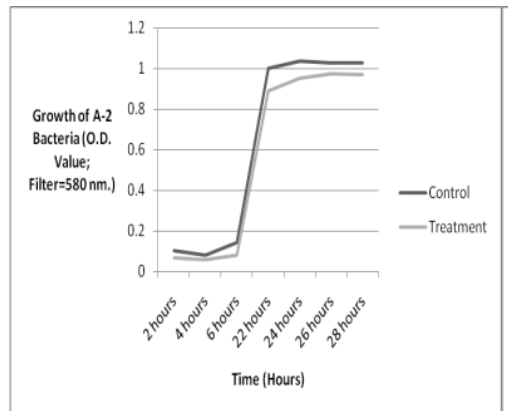

fig.4(e)

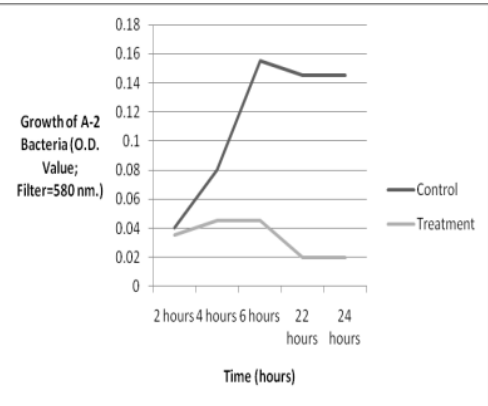

fig.4(f)

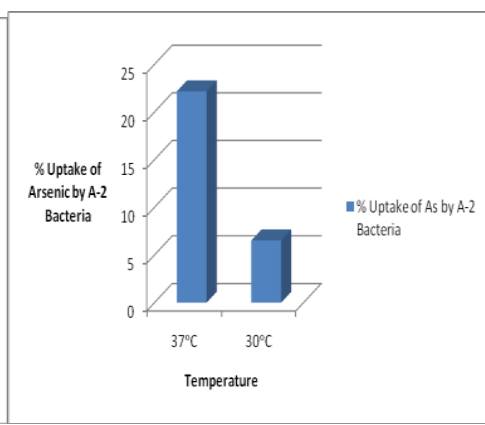

fig. $4(\mathrm{~g})$

fig. 4(e) growth of $300 \mu$ l. aliquot i.e $0.019 \mathrm{~g}$. of A-2 bacteria in $\mathrm{pH} 7$ medium at $37^{\circ} \mathrm{c}$ in control and treatment condition,(f) growth of $300 \mu \mathrm{l}$. aliquot i.e $0.019 \mathrm{~g}$. of A-2 bacteria in $\mathrm{pH} 7$ medium at $30^{\circ} \mathrm{c}$ and $(\mathrm{g}) \%$ optake of arsenic by $300 \mu$ l. aliquot i.e $0.019 \mathrm{~g}$. of A-2 bacteria in $\mathrm{pH} 7$ medium at $37^{\circ} \mathrm{c}, 30^{\circ} \mathrm{c}$.

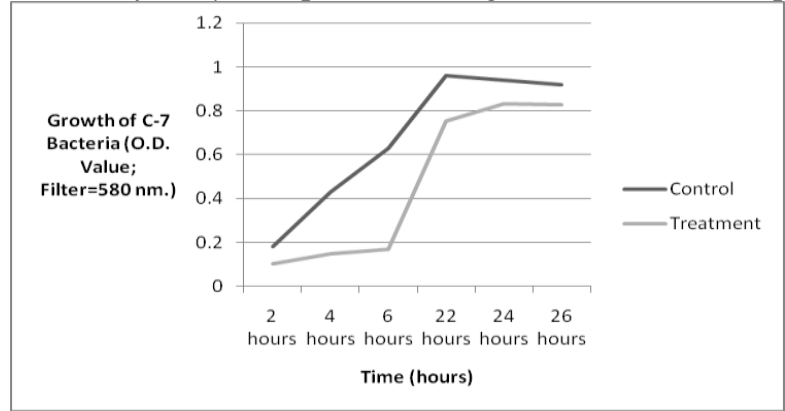

fig. 5(a)

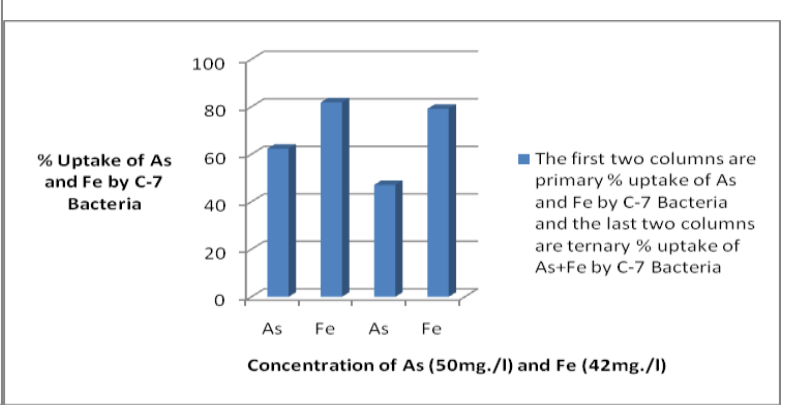

fig. 5(b)

fig. 5(a) growth curve of C-7 bacteria in presence of $50 \mathrm{mg} / \mathrm{l}$ of arsenic and $42 \mathrm{mg} / \mathrm{l}$ of iron at its optimum $\mathrm{pH}$ 7,biomass $0.0607 \mathrm{~g}$. of $700 \mu \mathrm{l}$. aliquot and $37^{\circ} \mathrm{c}$ temperature and (b) \%uptake of arsenic and iron by C-7 bacteria from primary solution (single metal solution) and \%uptake of arsenic and iron by $\mathrm{C}-7$ bacteria from ternary solution (mixed metals solution).

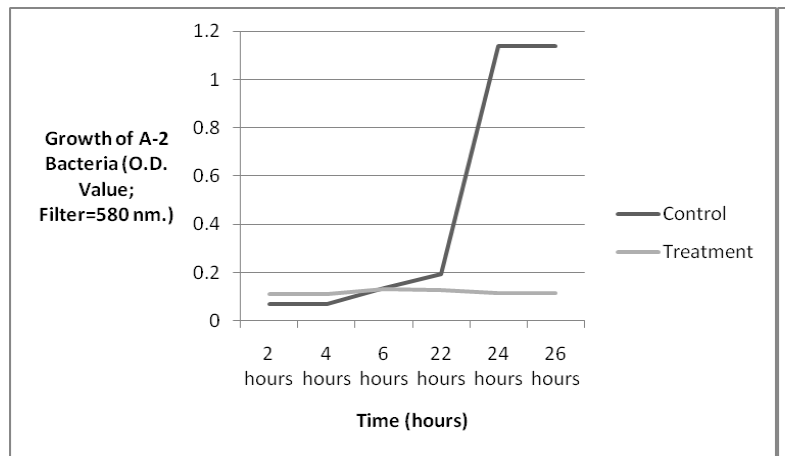

fig. 5(c)

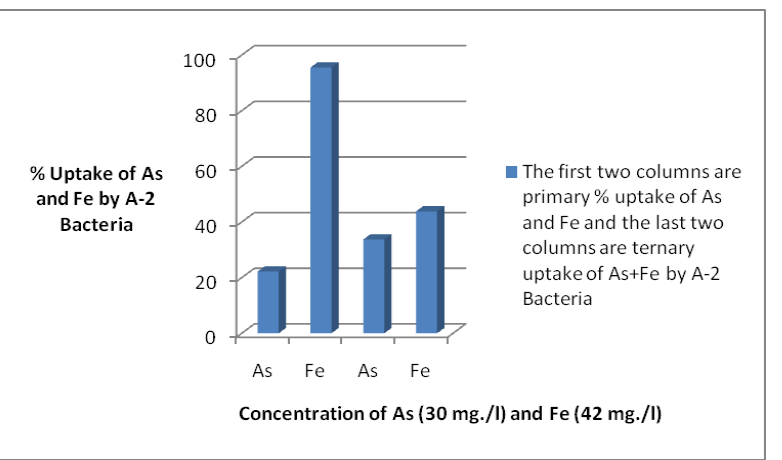

fig. 5(d) 
fig. 5(c) growth of A-2 bacteria in presence of $30 \mathrm{mg} / \mathrm{l}$ of arsenic and $42 \mathrm{mg} / \mathrm{l}$ of iron at its optimum $\mathrm{pH}$ 7 , biomass $0.019 \mathrm{~g}$. of $300 \mu \mathrm{l}$. aliquot and $37^{\circ} \mathrm{c}$ temperature and (d) \%uptake of arsenic and iron by A-2 bacteria from primary solution (single metal solution) and \%uptake of arsenic and iron by A-2 bacteria from ternary solution (mixed metals solution).

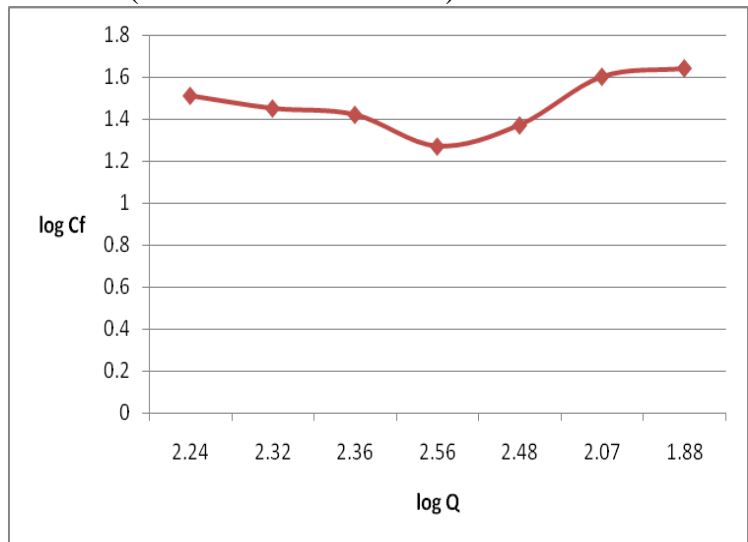

fig. 6(a)

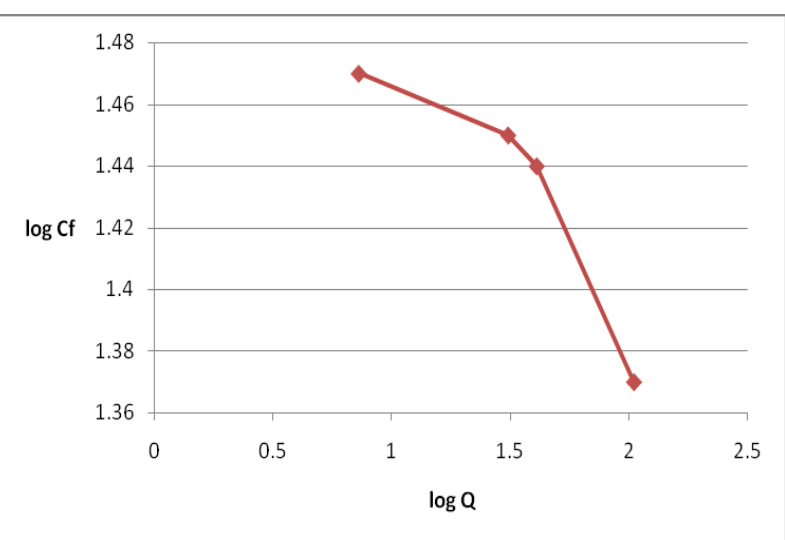

fig. 6(b)

fig.6(a). adsorption isotherm (Freundlich) for arsenic by Bacillus sp. strain CCBAU 51490 and 6(b) Bacillus subtilis subsp. subtilis strain DSM 10

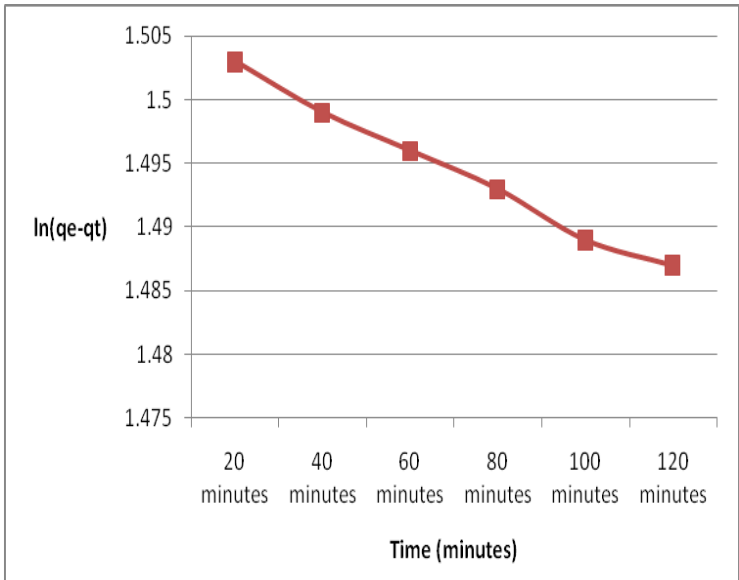

fig. 7(a)

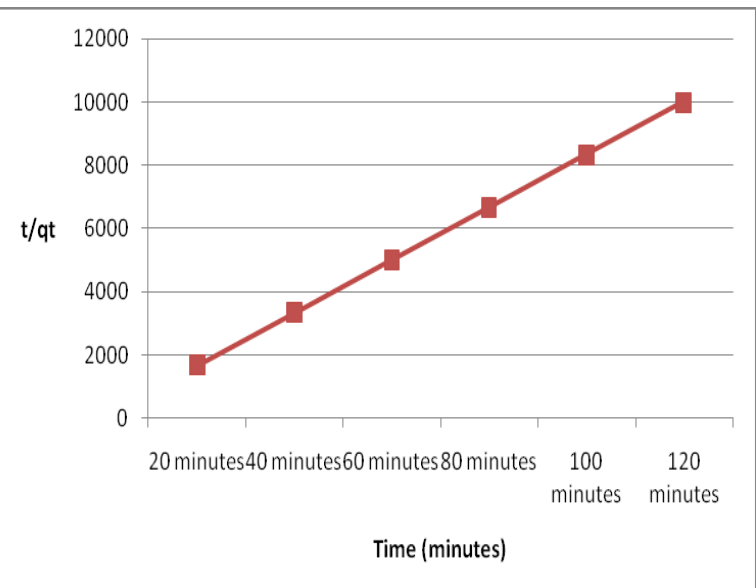

fig. 7(b)

fig. 7(a) first order kinetics for arsenic uptake by $300 \mu \mathrm{l}$ aliquot i.e $0.0312 \mathrm{~g}$. of $\mathrm{C}-7$ bacteria i.e Bacillus sp. strain CCBAU 51490 at $50 \mathrm{mg} / \mathrm{l}$ as concentration, $\mathrm{pH} 10,37^{\circ} \mathrm{c}$ temperature and (b) second order kinetics for arsenic uptake by $300 \mu \mathrm{l}$ aliquot i.e $0.0312 \mathrm{~g}$. of C-7 bacteria i.e Bacillus sp. strain CCBAU 51490 at $50 \mathrm{mg} / \mathrm{l}$ as concentration, $\mathrm{pH} 10,37^{\circ} \mathrm{c}$ temperature.

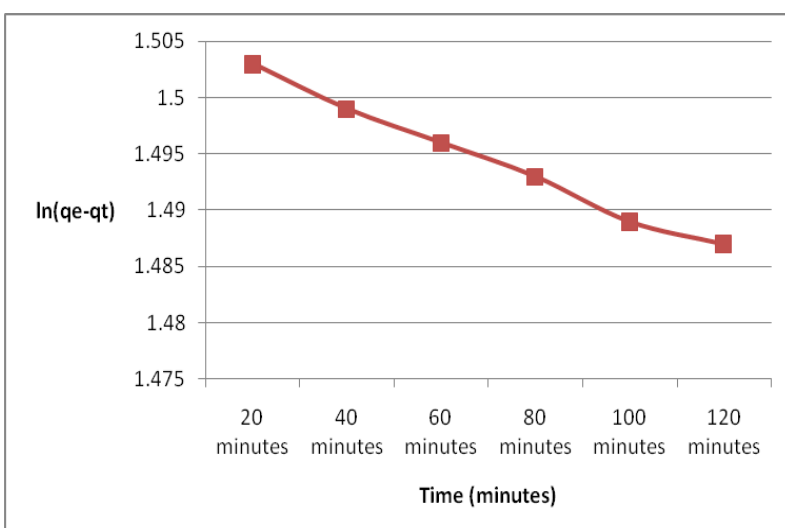

fig. 7(c)

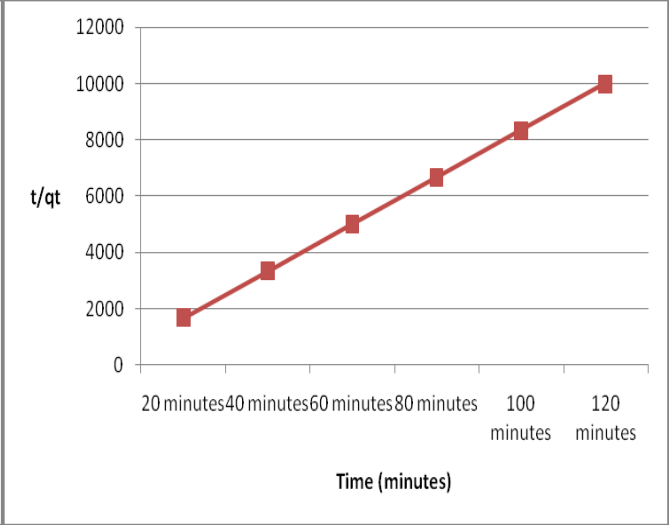

fig. 7(d)

fig. 7(c) first order kinetics for arsenic uptake by $300 \mu \mathrm{l}$ aliquot i.e $0.019 \mathrm{~g}$. of A-2 bacteria i.e Bacillus subtilis subsp. subtilis strain dsm 10 at $30 \mathrm{mg} / \mathrm{l}$ as concentration, $\mathrm{pH} 10,37^{\circ} \mathrm{c}$ temperature and (d) second order kinetics 
for arsenic uptake by $300 \mu \mathrm{l}$ aliquot i.e $0.019 \mathrm{~g}$. of A-2 bacteria i.e Bacillus subtilis subsp. subtilis strain DSM 10 at $30 \mathrm{mg} / \mathrm{l}$ as concentration, $\mathrm{pH} 10,37^{\circ} \mathrm{c}$ temperature.

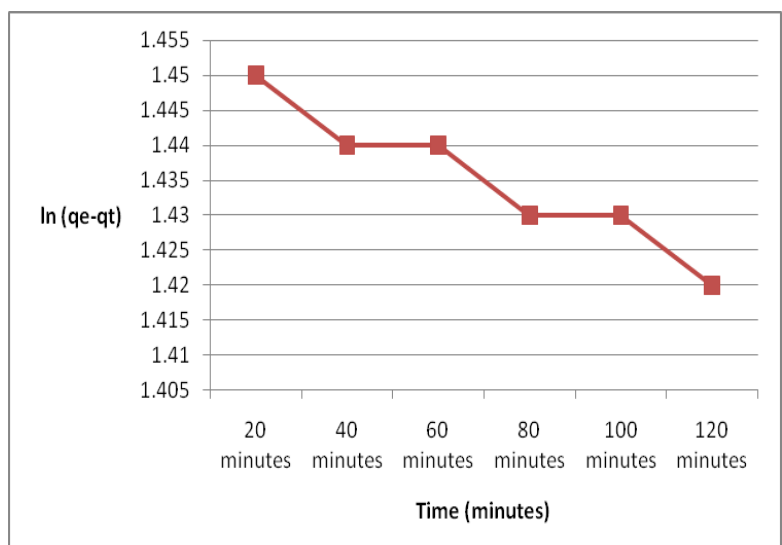

fig.8(a)

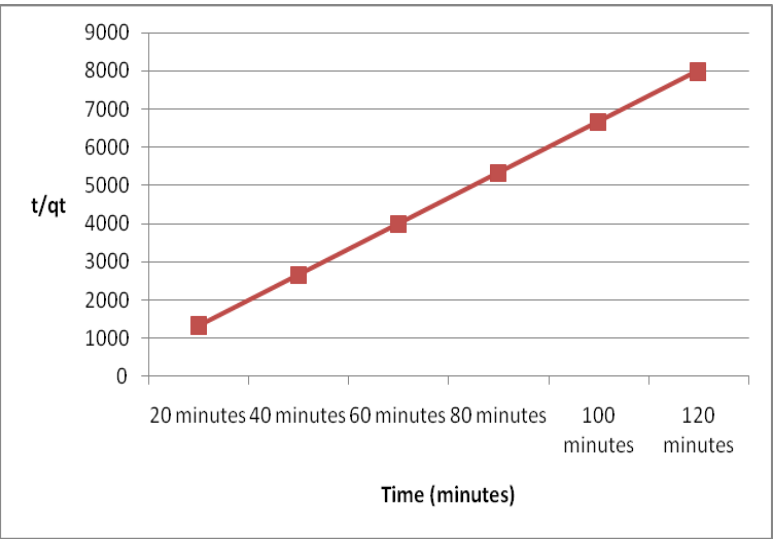

fig. 8(b)

fig. 8(a) first order kinetics for arsenic uptake by $300 \mu \mathrm{l}$ aliquot i.e $0.0312 \mathrm{~g}$. of C-7 bacteria i.e Bacillus sp.

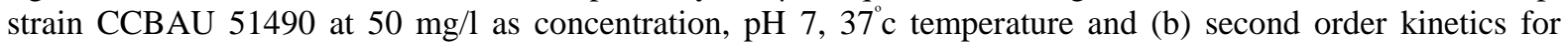
arsenic uptake by $300 \mu \mathrm{l}$ aliquot i.e $0.0312 \mathrm{~g}$. of C-7 bacteria i.e Bacillus sp.strain CCBAU 51490 at $50 \mathrm{mg} / \mathrm{l}$ as

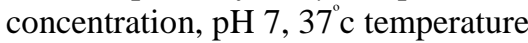

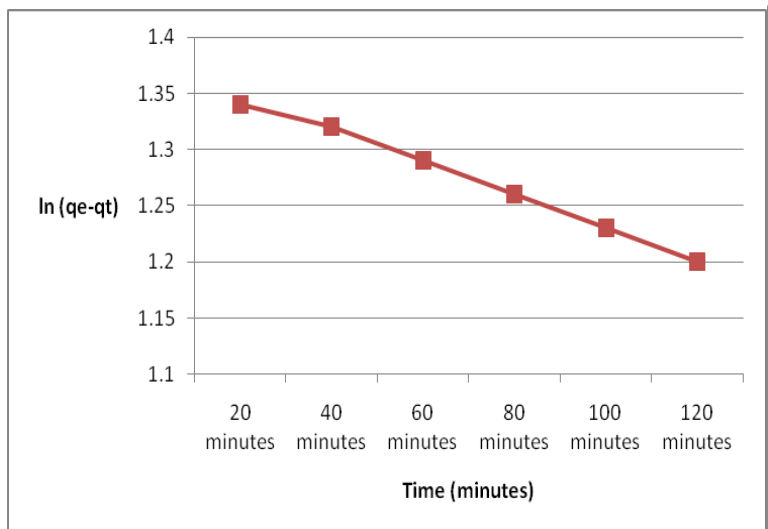

fig. 8(c)

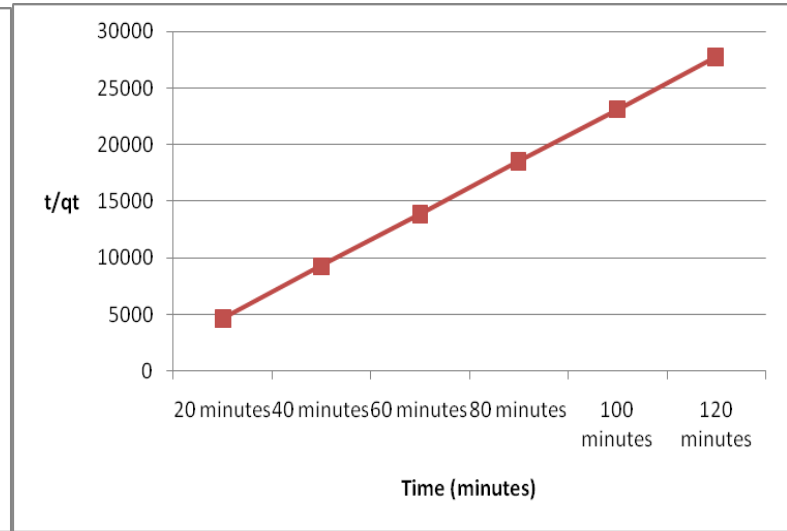

fig. $8(\mathrm{~d})$

fig. 8(c) first order kinetics for arsenic uptake by $300 \mu 1$ aliquot i.e $0.019 \mathrm{~g}$. of A-2 bacteria i.e Bacillus subtilis subsp. subtilis strain DSM 10 at $30 \mathrm{mg} / \mathrm{l}$ as concentration, $\mathrm{pH} 7,37^{\circ} \mathrm{c}$ temperature and (b) second order kinetics for arsenic uptake by $300 \mu \mathrm{l}$ aliquot i.e $0.019 \mathrm{~g}$. of A-2 bacteria i.e Bacillus subtilis subsp. subtilis strain DSM 10

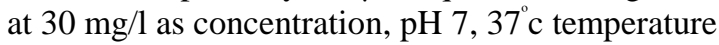

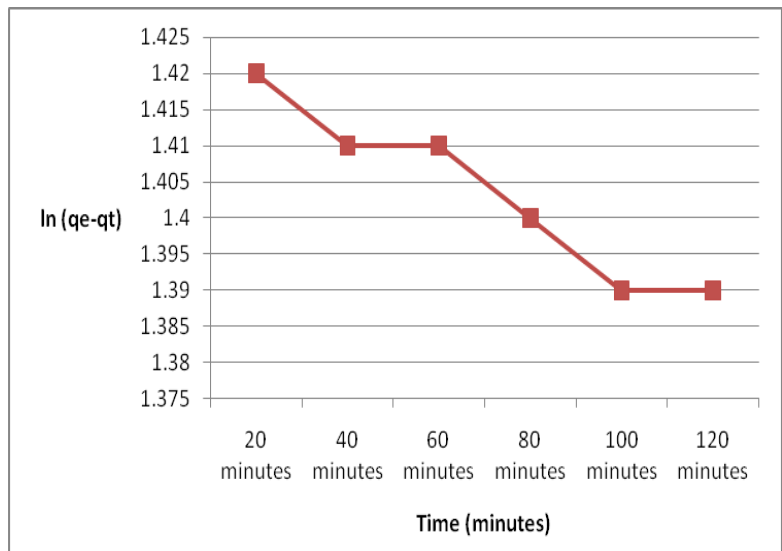

fig. 9(a)

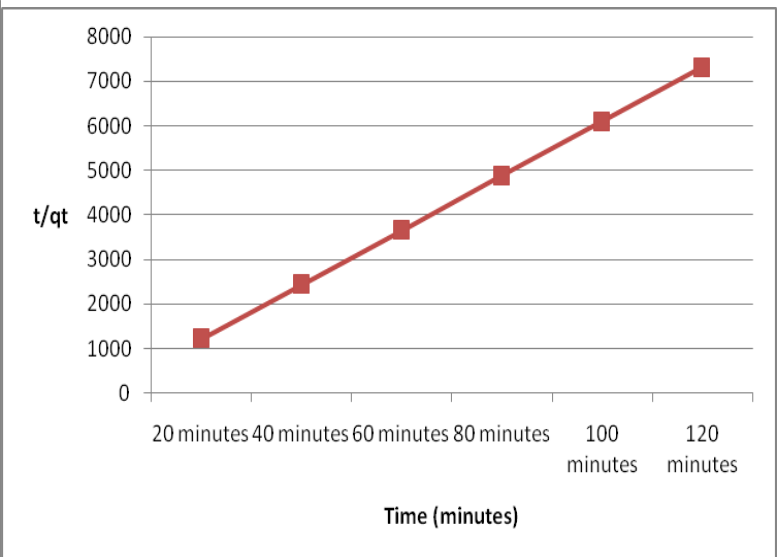

fig. 9(b)

fig. 9(a) first order kinetics for arsenic uptake by $500 \mu 1$ aliquot i.e $0.0449 \mathrm{~g}$. of C-7 bacteria i.e Bacillus sp.

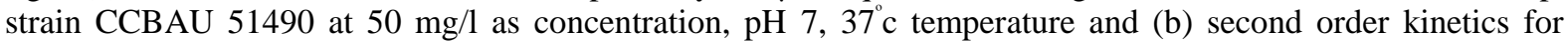


arsenic uptake by $500 \mu \mathrm{l}$ aliquot i.e $0.0449 \mathrm{~g}$. of C-7 bacteria i.e Bacillus sp. strain CCBAU 51490 at $50 \mathrm{mg} / \mathrm{l}$ as concentration, $\mathrm{pH} 7,37^{\circ} \mathrm{c}$ temperature

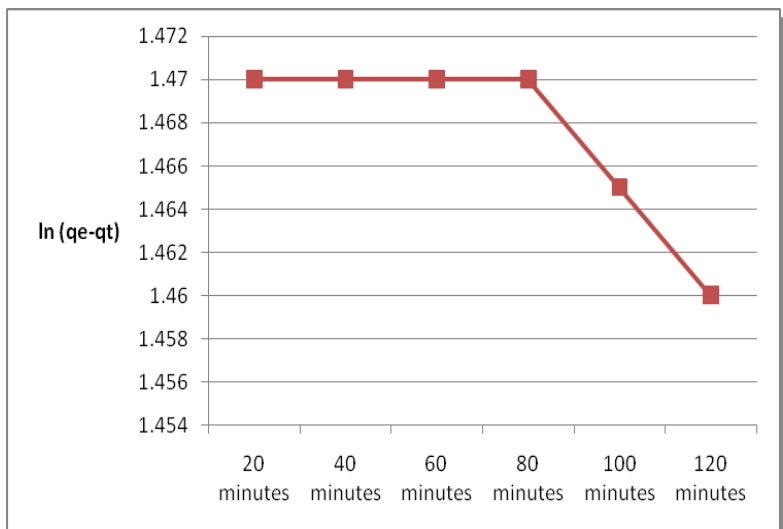

fig. $9(\mathrm{c})$

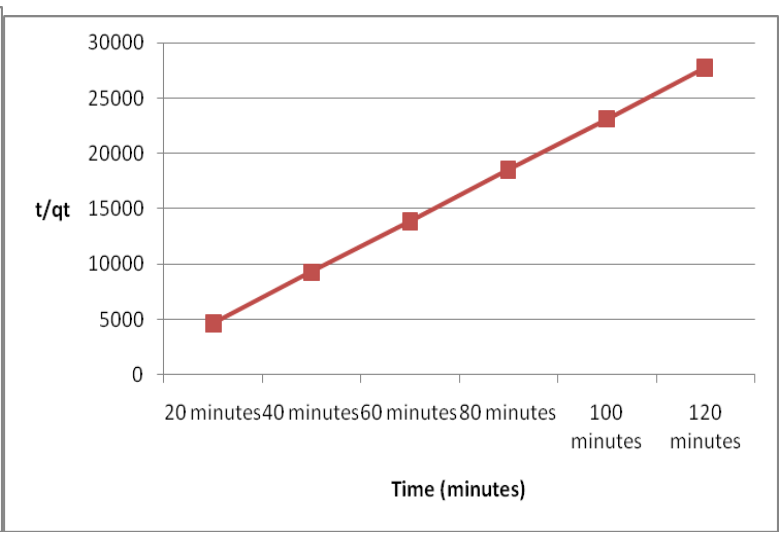

fig. $9(\mathrm{~d})$

fig. 9(c) first order kinetics for arsenic uptake by $500 \mu \mathrm{l}$ aliquot i.e $0.0252 \mathrm{~g}$. of A-2 bacteria i.e Bacillus subtilis

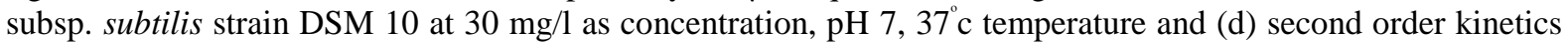
for arsenic uptake by $500 \mu \mathrm{l}$ aliquot i.e $0.0252 \mathrm{~g}$. of A-2 bacteria i.e Bacillus subtilis subsp. subtilis strain DSM 10 at $30 \mathrm{mg} / \mathrm{l}$ as concentration, $\mathrm{pH} 7,37^{\circ} \mathrm{c}$ temperature

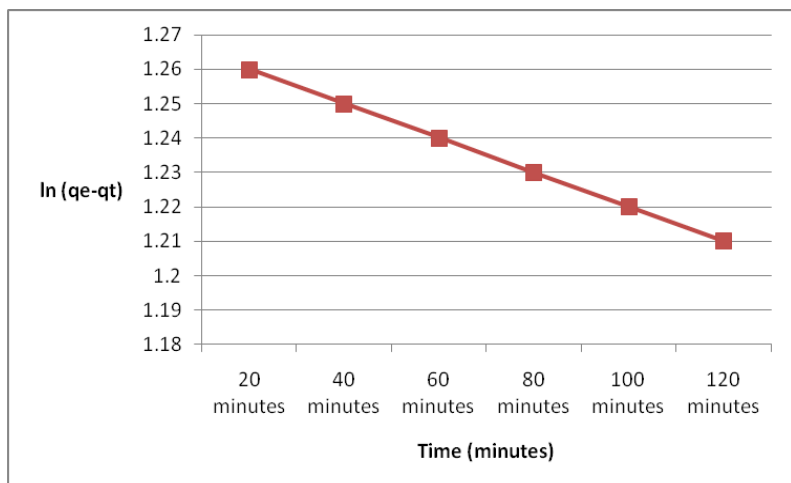

fig. 10(a)

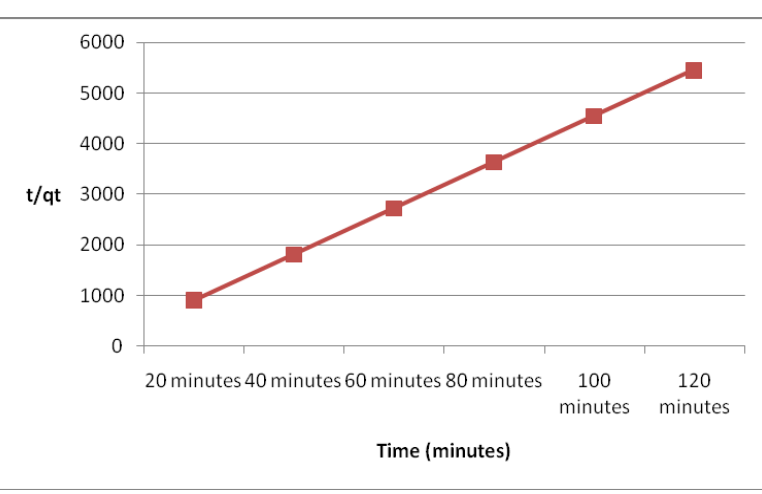

fig. 10(b)

fig. 10(a) first order kinetics for arsenic uptake by $700 \mu$ l aliquot i.e $0.0607 \mathrm{~g}$. of C-7 bacteria i.e Bacillus sp.

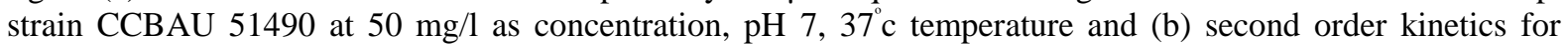
arsenic uptake by $700 \mu \mathrm{l}$ aliquot i.e $0.0607 \mathrm{~g}$. of c-7 bacteria i.e Bacillus sp. strain CCBAU 51490 at $50 \mathrm{mg} / \mathrm{l}$ as concentration, $\mathrm{pH} 7,37^{\circ} \mathrm{c}$ temperature

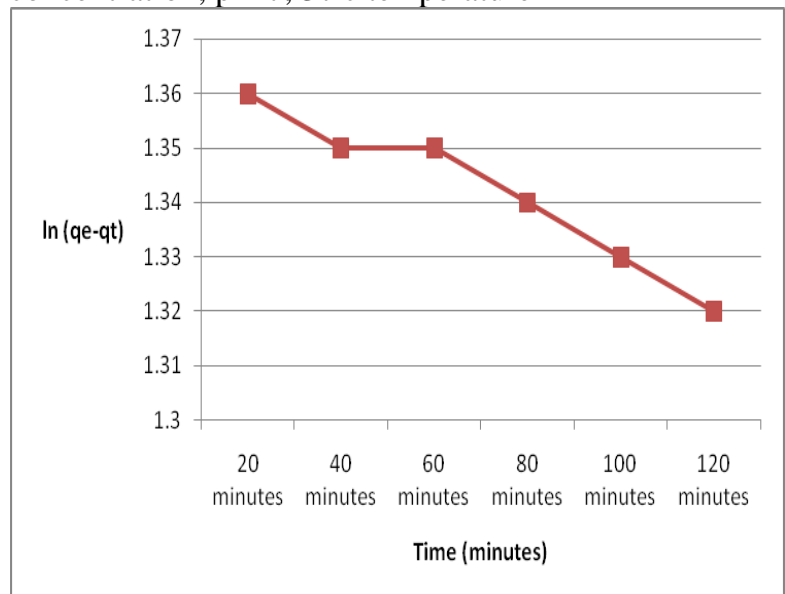

fig. 11(a)

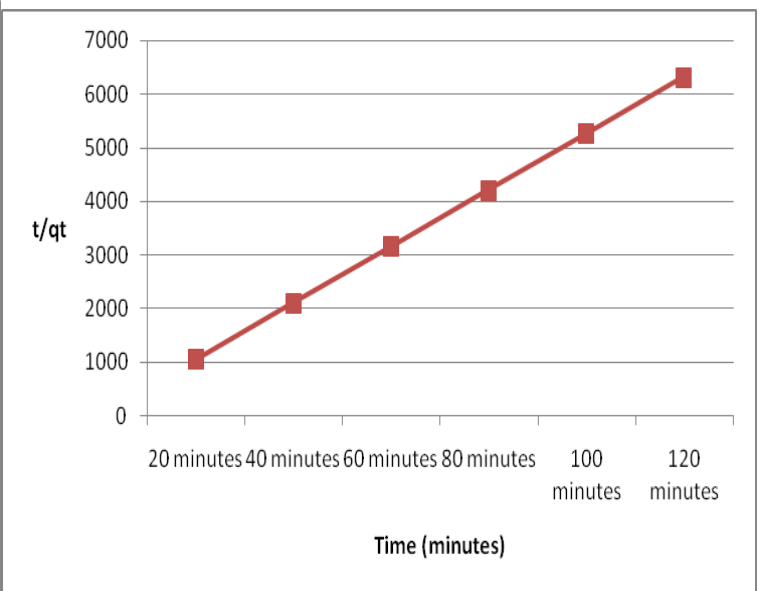

fig. 11(b)

fig. 11(a) first order kinetics for arsenic uptake by $900 \mu \mathrm{l}$ aliquot i.e 0.0792g. of C-7 bacteria i.e Bacillus sp.

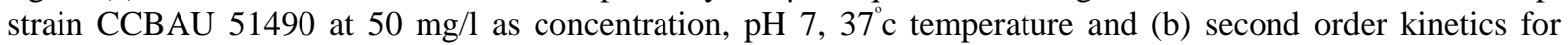
arsenic uptake by $900 \mu \mathrm{l}$ aliquot i.e $0.0792 \mathrm{~g}$. of C-7 bacteria i.e Bacillus sp. strain CCBAU 51490 at $50 \mathrm{mg} / \mathrm{las}$ concentration, $\mathrm{pH} 7,37^{\circ} \mathrm{c}$ temperature 


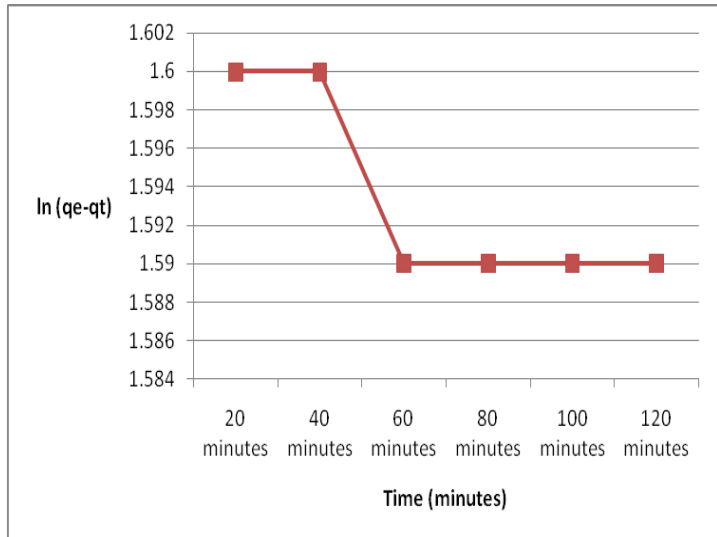

fig. 12(a)

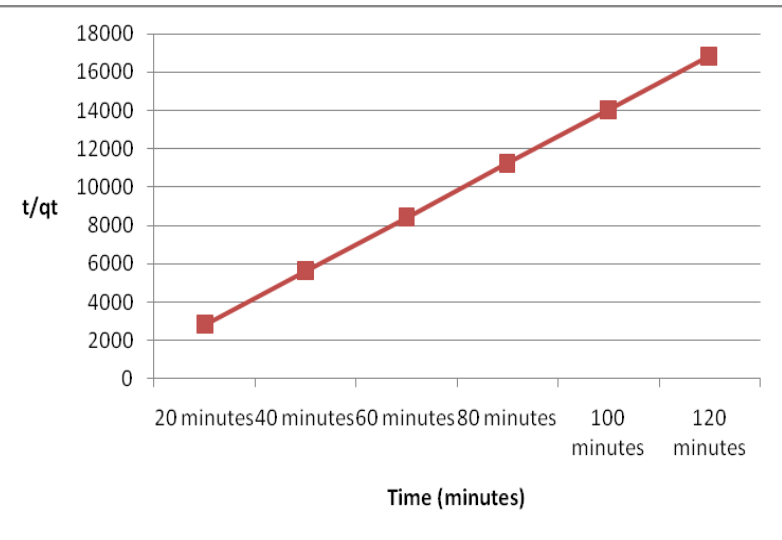

fig. 12(b)

fig. 12(a) first order kinetics for arsenic uptake by $700 \mu \mathrm{l}$ aliquot i.e $0.0607 \mathrm{~g}$. of C-7 bacteria i.e Bacillus sp. strain CCBAU 51490 at $50 \mathrm{mg} / \mathrm{l}$ as concentration, $\mathrm{pH} \mathrm{7,30}{ }^{\circ} \mathrm{c}$ temperature and (b) second order kinetics for arsenic uptake by $700 \mu 1$ aliquot i.e $0.0607 \mathrm{~g}$. of C-7 bacteria i.e Bacillus sp. strain CCBAU 51490 at $50 \mathrm{mg} / \mathrm{l}$ as concentration, $\mathrm{pH} 7,30^{\circ} \mathrm{c}$ temperature

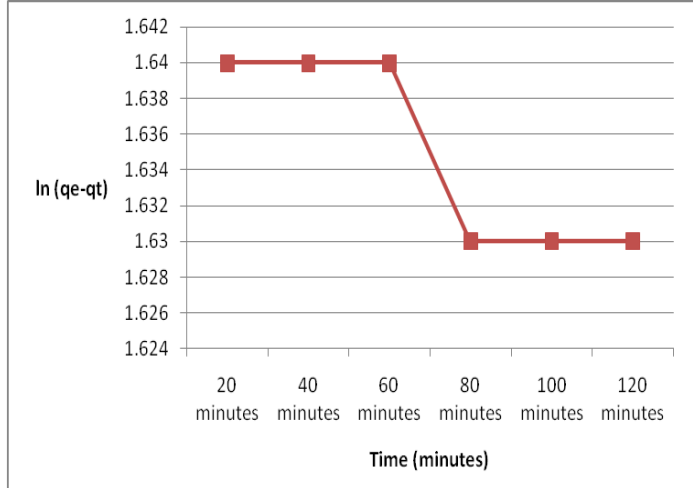

fig. 13(a)

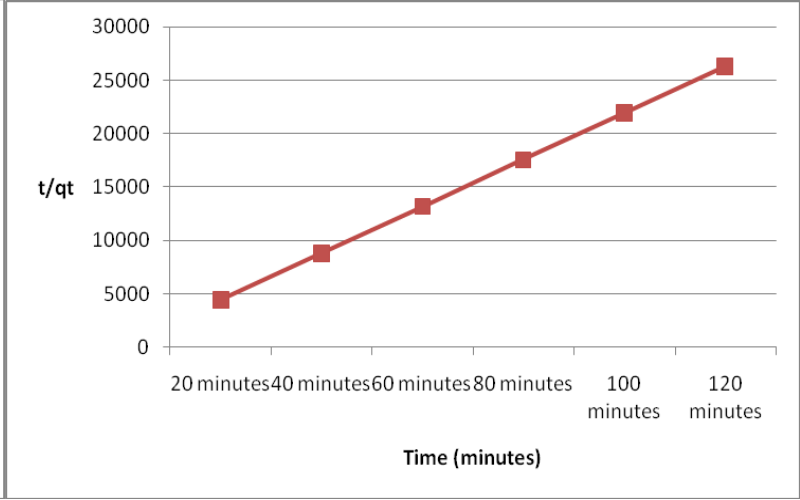

fig. 13(b)

fig. 13(a) first order kinetics for arsenic uptake by $700 \mu$ aliquot i.e $0.0607 \mathrm{~g}$. of C-7 bacteria i.e Bacillus sp.

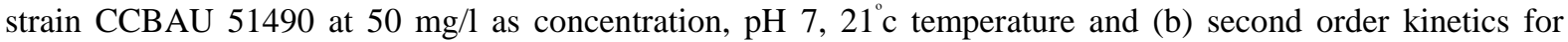
arsenic uptake by $700 \mu \mathrm{l}$ aliquot i.e $0.0607 \mathrm{~g}$. of C-7 bacteria i.e Bacillus sp. strain CCBAU 51490 at $50 \mathrm{mg} / \mathrm{l}$ as concentration, $\mathrm{pH} 7,21^{\circ} \mathrm{c}$ temperature

\section{References}

[1]. Azza. A. Abou Zeid,Wesam A. Hassanein, Hedayat M. Salama and Ghada A. A. Fahd., 2009. Biosorption of Some Heavy Metal Ions Using Bacterial Species Isolated from Agriculture Waste Water Drains in Egypt. Journal of Applied Scienes Research, 5(4): 372-383.

[2]. Babak, L., Šupinova, P., Zichova, M., Burdychova, R., Vitova, E, 2012. Biosorption Of Cu, Zn and Pb by Thermophilic Bacteria Effect Of Biomass Concentration On Biosorption Capacity. Acta Univ. Agric. Et Silvic.Mendel. Brun., LX, No. 5, pp. 9-18

[3]. Binkley, J. and Simpson, J.A., 2003. Heavy metals in wastewater treatment processes. In: The Handbook of Water and Wastewater Microbiology. Mara D andHoran N (eds). London: Academic Press p. 597-610.

[4]. Borrok, D., Aumend, K., Jeremy B. Fein, 2006. Significance of ternary bacteria-metal-natural organic matter complexes determined through experimentation and chemical equilibrium modeling. Chemical Geology 238: 44-62.

[5]. Ferreira M.A.S.S., Lund BM. 1987. The influence of $\mathrm{pH}$ and temperature on initiation of growth of Salmonella spp. Lett Appl Microbiol 5:67-70.

[6]. Foo, K.Y. and Hameed, B.H., 2010. Insights into the modeling of adsorption isotherm systems.Chemical Engineering Journal, 156: $2-10$.

[7]. Jefferies, DJ; Firestone, P.,1984. "Chemical analysis of some coarse fish from a Suffolk river carried out as part of the preparation for the first release of captive-bred otters", J Otter Trust., $1 ; 17-22$.

[8]. John, A.C., Lara, I.O., Victor, A and Oladunni, O., 2011.Equilibrium and Kinetic Studies of the Biosorption of Heavy Metal (Cadmium) on Cassia siamea Bark American-Eurasian Journal of Scientific Research 6 (3): 123-130.

[9]. Parungao Marilen M.,Tacata Ptricia S.,Christopher Ray G. Tanayan and Trinidad Lorele C.,2007.Biosorption of Copper,Cadmium and Lead by Copper-Resistant Bacteria Isolated from Mogpog River,Marinduque,Philippine Journal of Science,136(2): 155-165.

[10]. Pathak, R.K. and Dikshit, A.K., 2011. Isolation and Characterization of Bacterial Strains to be Used as Biosorbent for Removal of Atrazine from Wastewater. 2nd International Conference on Environmental Science and Technology. IPCBEE vol.6. IACSIT Press, Singapore

[11]. Preetha, B.,Viruthagiri,T.,2007.Batch and continuous biosorption of chromium(VI)by Rhizopus arrhizus.Separation and Purification Technology 57:126-133. 
[12]. Samulson, P., Wernerus, H., Svedberg, M and Stahl, S. 2000. Staphylococcal surface display of metal-binding polyhistidyl peptides. Appl Environ Microbiol 66(3): 1243-1248.

[13]. Sengupta, D., Mitra, A.K. and Shyam Choudhury, S., 2013. Identification and Characterization of Effectively Arsenic Tolerant Bacterial Strains from the Potential Arsenic Contaminated site in 24 Parganas (North) District of West-Bengal, India.Nature Environment and Pollution Technology. 12(2): 303-308.

[14]. Vieira, RHSF and Volesky, B, 2000. "Biosorption: a solution to pollution”, Int Microbiol., 3; 17-24.

[15]. Vijayaraghavan, K; Yun, YS, 2008. "Bacterial biosorbents and biosorption", Biotechnology Advances., 26; $266-291$.

[16]. Volesky, B and Holan, ZR, 1995. "Biosorption of heavy metals", Biotechnol Prog., 11; 235-250.

[17]. Tarangini, K., 2009. Biosorption of Heavy Metals using Individual and Mixed cultures of Pseudomonas aeruginosa and Bacillus subtilis. Thesis of Master of Technology (Research) in Chemical Engineering.

[18]. Yang, C.P., 2007. Biosorption Of Copper(Ii) And Chromium(Vi) Onto Activated Sludge : Isotherms and Kinetic Models. Master of Science Thesis. University Sains Malaysia

[19]. Yang, X; Duri, BAl ,2005. “Kinetic modeling of liquid-phase adsorption of reactive dyes on activated carbon”, J. Colloid Interface Sci., 287; 25-34.

[20]. 20.Zhu, J., 2010. Sorption of Trace Elements by Biotic and Abiotic Soil Components and Their Composites.Ph.D Thesis in Agrobiology and Agrochemistry.

[21]. http://water.epa.gov/drink/contaminants 